Japanese Journal of Herpetology 10(2) : 39-41. 1983.

\title{
Tooth Count Variation in the Japanese Salamanders
}

\section{Male Hynobius nigrescens}

\author{
Masafumi Matsui*, Shingo TANABE** and Yasuhiro KoKURYo***
}

The small Eurasian salamanders of the genus Hynobius possess series of maxillary, premaxillary, vomerine, and mandible teeth. The number of teeth in the vomerine series has once been reported for several species by Sato (1943), but little is known about variation in the tooth count of each series. We have been studying this subject and report the results on Hynobius nigrescens in this short communication.

Thirty-eight adult males of Hynobius nigrescens collected at Okushiobara, Tochigi Prefecture on 4 May 1978 were utilized. They were fixed in 10\% formalin and preserved in $70 \%$ ethanol. Their snout-vent length (SVL) and head length (HL) ranged from 60.5 to 73.4 ( $\overline{\mathrm{X}}=66.4 \pm 0.94$ (2SE)) $\mathrm{mm}$, and from 14.4 to 19.9 ( $\overline{\mathrm{X}}=16.6$ $\pm 0.40) \mathrm{mm}$, respectively. Observations and counting were made under a Wild binocular microscope at the magnification of 6-10 times. Cast-off teeth were excluded from the count.

The number of teeth in the upper jaw tooth series (maxillary + premaxillary) varied between 66 and 82 , and the mean was $73.3 \pm 1.4$ (2SE). The number of teeth had no significant correlation with SVL (Fig. 1) or HL (p>.05). The vomerine tooth series formed a "V"shape. The number of teeth on one side varied between 18 and $25(\bar{X}=21.7 \pm 1.0)$, and the total number of right and left sides varied between 37 and $49\left(\overline{\mathrm{X}}=43.3_{ \pm 2.0}\right)$. The difference in the number of teeth between each side ranged from 0 to 4 , and in 13 individuals the right side had a larger number of teeth than the left side. The situation was reversed in 17

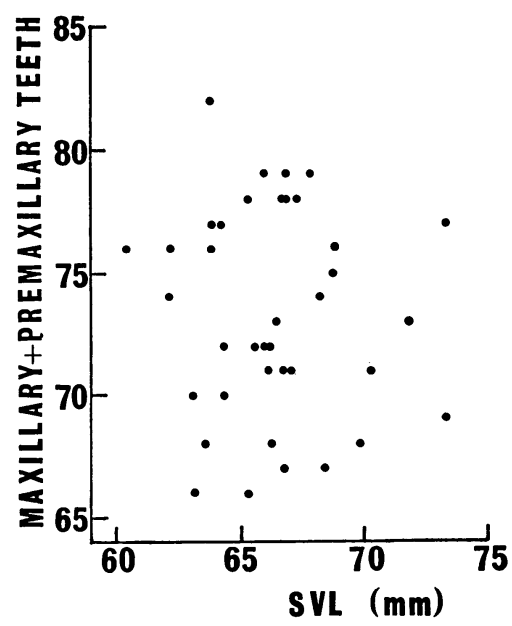

Fig. 1. Relationship between SVL and numbers of of upper jaw teeth in male Hynobius nigrescens from Tochigi.

* Biological Laboratory, Yoshida College, Kyoto University, Yoshida Nihonmatsu-cho, Sakyo-ku, Kyoto 606 Japan. 606 京都市左尔区吉田二本松町, 京都大学教食部生物学教室

** Tôjiin-minami-cho 5-40, Kita-ku, Kyoto 603 Japan. 603 京都市北区等持院南町5-40

*** Kuruma-cho 4, Shizuoka, Shizuoka 420 Japan. 420 静岡市車町 4 

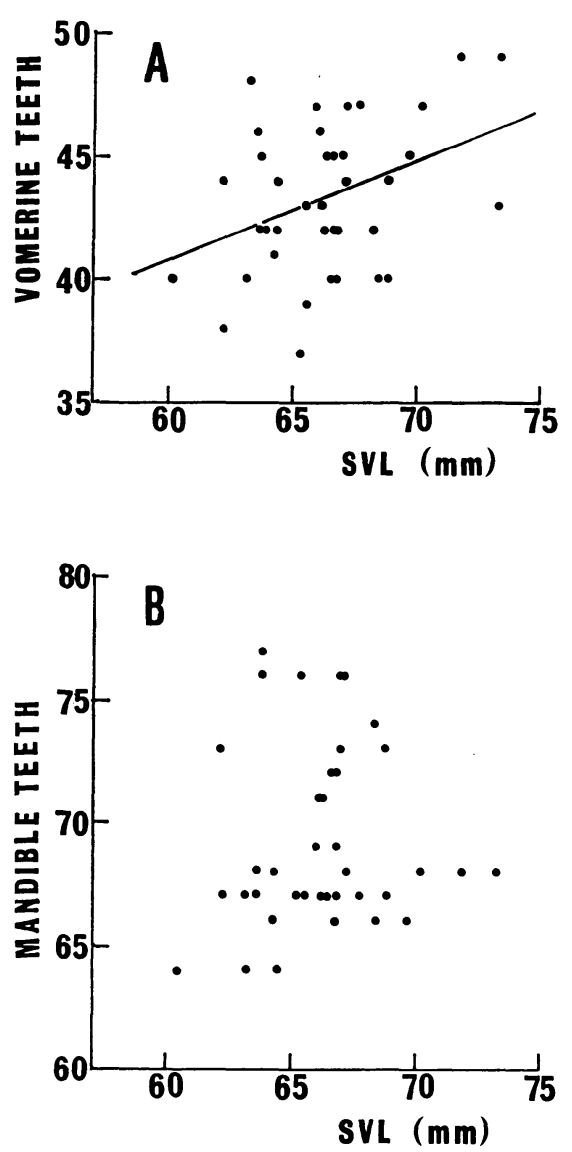

Fig. 2. Relationships between SVL and numbers of vomerine teeth (A) and mandible teeth (B) in male Hynobius nigrescens from Tochigi. Regression equation fitted by the least squares method for Fig. 2a is $\mathrm{Y}=0.399 \mathrm{X}+16.81 \quad(r=0.381)$, where $\mathrm{X}=\mathrm{SVL}$ and $\mathrm{Y}=$ number of vomerine teeth.

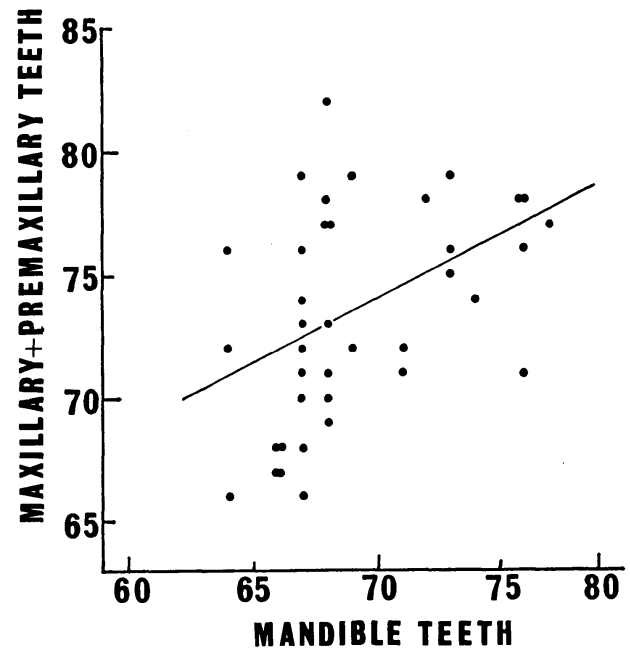

Fig. 3. Relationship between numbers of mandible teeth $(\mathrm{X})$ and upper jaw teeth (Y) in male Hynobius nigrescens from Tochigi. Regression equation is $\mathrm{Y}=$ $0.491 \mathrm{X}+39.39(r=0.428)$.

individuals, and the number of teeth on each side was the same in the remaining 8 individuals. Although the number of vomerine teeth (Y) had no correlation with HL, it significantly correlated with SVL $(X)$ : in the individuals with larger SVL, the number of vomerine teeth was larger $(\mathrm{Y}=0.399 \mathrm{X}$ $+16.81, \quad r=0.381, \quad .01<\mathrm{p}<.02 ; \quad$ Fig. 2a) The number of mandible teeth varied between 64 and $77(\overline{\mathrm{X}}=69.1 \pm 1.2)$, and had no correlation with SVL (Fig. 2b) or HL. Although no significant correlation was found between the number of upper jaw teeth and the number of vomerine teeth, the number of upper jaw teeth (Y) positively correlated with that of mandible teeth $(\mathrm{X}): \mathrm{Y}=0.491 \mathrm{X}+39.39, r=0.428, .01>\mathrm{p}>.005$; Fig. 3). When the variability of the tooth count was estimated by the coefficient of variation $(\mathrm{CV})$, the vomerine series was most variable $(\mathrm{CV}=7.02)$, and the upper jaw $(\mathrm{CV}=5.82)$ and mandible $(\mathrm{CV}=5.38)$ series were similarly variable. Thus, the vomerine tooth series, though generally regarded as taxonomically diagnostic in its shape, was judged to be less stable in the number of included teeth than the other two series. 
Although the number of teeth in the upper and lower jaw series has till now never been reported for this species, the number of vomerine teeth series reported by Sato (1943:20) for a male specimen from Himi, Toyama Prefecture, was within the variation range reported here.

\section{Literature Cited}

Sato, I. 1943. A monograph of the tailed batrachians of Japan. Nippon Shuppan-sha, Osaka, 520p. (In Japanese.)

\section{要 旨}

日本産サンショウウオの歯数の变異 1. クロサンショウウオ\}

松井 正文・田辺 真吾・国領 康弘

杤木県奥塩原産クロサンショウウオठ成体38個体について, 上顎・鋤骨・不顎の各歯列の歯 数の変異を調べた。鋤骨歯列の歯数と体長との間には正の相関があり，上・下顎の歯数の間に も相関があった。変動係数で比較すると, 鋤骨崡列で最も歯数の变異が高かった。 